\title{
Cardiovascular effects of tolazoline and ranitidine
}

\author{
A BUSH, C M BUSST, W B KNIGHT, AND E A SHINEBOURNE \\ Departments of Respiratory Physiology and Paediatric Cardiology, Brompton Hospital, London
}

SUMmARY The cardiovascular effects of ranitidine were studied in 12 children with congenital heart disease who had been given tolazoline as a pulmonary vasodilator. Ranitidine was given as prophylaxis against gastrointestinal haemorrhage induced by tolazoline. Tolazoline $1-2 \mathrm{mg} / \mathrm{kg}$ caused significant falls in pulmonary and systemic vascular resistances and a rise in heart rate. After intravenous administration of ranitidine $3 \mathrm{mg} / \mathrm{kg}$ both resistances rose again and neither resistance then differed significantly from baseline levels. Heart rate also fell and the final heart rate was significantly below baseline levels. We conclude that there may be $\mathrm{H}_{2}$ receptors within the pulmonary and systemic circulations and that tolazoline may mediate some of its effects through these $\mathrm{H}_{2}$ receptors rather than by alpha adrenergic receptor blockade. The safety of $\mathrm{H}_{2}$ blockade in children, particularly those with pulmonary hypertension, needs further investigation.

Tolazoline is an alpha adrenergic blocking agent that has been widely used as a pulmonary vasodilator, particularly in babies and small children. ${ }^{1-3}$ Indications for its use include preoperative assessment of pulmonary vascular damage in children with congenital heart disease, ${ }^{1}$ management of postoperative pulmonary hypertensive crisis, ${ }^{2}$ and pulmonary hypertension secondary to pulmonary parenchymal disorders. ${ }^{3}$ Although effective, tolazoline is associated with a high incidence of complications, including systemic hypotension, renal failure, and acute upper gastrointestinal haemorrhage, this last effect being presumably related to its $\mathrm{H}_{2}$ agonist properties. ${ }^{3}$ It would be logical to try to prevent this potentially life threatening side effect by the prophylactic administration of an $\mathrm{H}_{2}$ blocker, such as ranitidine or cimetidine.

The specific $\mathrm{H}_{2}$ antagonist ranitidine has been used to treat many children with peptic ulcer, short bowel syndrome, and other gastrointestinal conditions. ${ }^{4}$ It has also been administered to more than 2400 women in labour as prophylaxis against gastric aspiration. ${ }^{5}$ There were no ill effects on the babies, despite equal ranitidine concentrations in umbilical cord and maternal blood when it was given intravenously. ${ }^{5}$ On this basis, ranitidine seems to be a safe prophylaxis against upper gastrointestinal bleeding induced by tolazoline. It has been suggested, however, that tolazoline may affect the pulmonary circulation through histamine receptors. ${ }^{6}$ The less selective $\mathrm{H}_{2}$ blocker cimetidine may antagonise the pulmonary vasodilator effect of tolazoline. ${ }^{2}$

The aim of this study was to assess the effects of tolazoline and ranitidine on the pulmonary and systemic circulation in children with pulmonary vascular disease secondary to congenital heart disease who required diagnostic or therapeutic administration of pulmonary vasodilators.

\section{Patients and methods}

Patients. Details of the 12 children studied are given in the Table. Case 1 was studied in the intensive care unit to optimise pulmonary vasodilator treatment, and the other children were studied in the cardiac catheterisation laboratory as part of the assessment of pulmonary vascular disease. In no child was the arterial duct patent at the time of study. Cases 2, 4, and 10 had undergone palliative mustard operations before the study. Informed consent was obtained from the parents in all cases before the procedure, and the protocol had been approved by the ethics committee of our hospital.

Methods. Full details of the measurement techniques have been published elsewhere. ${ }^{78}$ In summary, the children were anaesthetised for the duration of the study using intravenous etomidate. They were paralysed and ventilated through a close fitting endotracheal tube. Stability and adequacy of ventilation throughout the study were checked by 
Table Details of patients studied, in descending order of baseline pulmonary vascular resistance

\begin{tabular}{|c|c|c|c|c|c|c|c|c|}
\hline \multirow[t]{2}{*}{$\begin{array}{l}\text { Case } \\
\text { No }\end{array}$} & \multirow[t]{2}{*}{$\begin{array}{l}\text { Age } \\
\text { (yrs) }\end{array}$} & \multirow[t]{2}{*}{ Diagnosis } & \multicolumn{2}{|c|}{$\begin{array}{l}\text { Pulmonary vascular resistance } \\
\left(\mathrm{mm} \mathrm{Hg} / \mathrm{ll} / \mathrm{min} / \mathrm{m}^{2}\right)\end{array}$} & \multicolumn{2}{|c|}{$\begin{array}{l}\text { Pulmonary blood flow } \\
\left(\mathrm{l} / \mathrm{min} / \mathrm{m}^{2}\right)\end{array}$} & \multicolumn{2}{|c|}{$\begin{array}{l}\text { Pulmonary artery pressure } \\
(\mathrm{mm} \mathrm{Hg})\end{array}$} \\
\hline & & & Baseline & Best & Baseline & Best & Baseline & Best \\
\hline 1 & 1 & Endomyocardial fibroelastosis & $25 \cdot 00$ & $14 \cdot 10$ & $2 \cdot 95$ & $3 \cdot 55$ & 88 & 59 \\
\hline 2 & 7 & $\begin{array}{l}\text { Transposition of the great arteries, } \\
\text { ventricular septal defect. }\end{array}$ & $16 \cdot 79$ & $16 \cdot 39$ & $3 \cdot 46$ & 3.91 & 63 & 63 \\
\hline 3 & 5 & $\begin{array}{l}\text { Down's syndrome, venticular septal } \\
\text { defect, patent foramen ovale }\end{array}$ & $9 \cdot 57$ & 8.74 & $5 \cdot 23$ & $6 \cdot 29$ & 56 & 53 \\
\hline 4 & 4 & Transposition of the great arteries & $11 \cdot 80$ & $8 \cdot 50$ & $2 \cdot 60$ & $4 \cdot 40$ & 38 & 38 \\
\hline 5 & 4 & $\begin{array}{l}\text { Atrioventricular septal defect. } \\
\text { Down's syndrome }\end{array}$ & $9 \cdot 37$ & $8 \cdot 36$ & $5 \cdot 79$ & $6 \cdot 84$ & 62 & 62 \\
\hline 6 & 0.8 & $\begin{array}{l}\text { Patent arterial duct, broncho- } \\
\text { pulmonary dysplasia }\end{array}$ & $8 \cdot 30$ & $7 \cdot 35$ & 2.95 & $3 \cdot 60$ & 30 & 30 \\
\hline 7 & 2 & $\begin{array}{l}\text { Atrioventricular septal defect. } \\
\text { pulmonary artery banded }\end{array}$ & $7 \cdot 90$ & $6 \cdot 70$ & $2 \cdot 80$ & $2 \cdot 80$ & 25 & 18 \\
\hline 8 & 4 & Aortopulmonary window & $6 \cdot 63$ & $4 \cdot 68$ & $9 \cdot 50$ & $11 \cdot 54$ & 68 & 59 \\
\hline 9 & 4 & $\begin{array}{l}\text { Patent arterial duct, ventricular } \\
\text { septal defect, parachute mitral } \\
\text { valve }\end{array}$ & $6 \cdot 08$ & $4 \cdot 46$ & $4 \cdot 85$ & $5 \cdot(00$ & 55 & 44 \\
\hline 10 & 3 & $\begin{array}{l}\text { Transposition of the great arteries, } \\
\text { pulmonary artery banded }\end{array}$ & $5 \cdot 30$ & $5 \cdot 10$ & 2.90 & $3 \cdot 60$ & 24 & 24 \\
\hline 11 & 4 & $\begin{array}{l}\text { Double outlet right ventricle, patent } \\
\text { arterial duct }\end{array}$ & $3 \cdot 87$ & $3 \cdot 54$ & $9 \cdot 68$ & $9 \cdot 68$ & 40 & 31 \\
\hline 12 & 6 & $\begin{array}{l}\text { Ventricular septal defect, patent } \\
\text { arterial duct, coarctation }\end{array}$ & $3 \cdot 80$ & $3 \cdot 40$ & $4 \cdot 40$ & $4 \cdot 40$ & 27 & 23 \\
\hline
\end{tabular}

monitoring end tidal gases using remote respiratory mass spectrometry. The children were initially ventilated with air. Catheters filled with fluid were introduced percutaneously into the femoral artery and vein and positioned in the aorta and pulmonary artery, respectively. Any necessary diagnostic procedures, including measurement of left and right atrial pressures but excluding angiography, were performed before the measurements were made.

When a steady respiratory state had been attained, as defined by an end tidal carbon dioxide tension stable to within $0.25 \mathrm{kPa}$ over several minutes,${ }^{8}$ measurements of aortic and pulmonary artery pressure and pulmonary and (where possible) systemic blood flow were made. Flow was measured by the direct Fick principle, oxygen consumption being measured by remote respiratory mass spectrometry ${ }^{78}$ and blood oxygen contents calculated using the subroutine of Kelman. ${ }^{9}$ The respiratory exchange ratio was measured on air and used in the equations to calculate oxygen consumption on $100 \%$ oxygen, as described elsewhere. ${ }^{10}$

After the measurements on air the children were ventilated with $100 \%$ oxygen. Comparability of ventilation and adequacy of nitrogen washout were checked by monitoring the expired gases. After 10 minutes on $100 \%$ oxygen, by which time nitrogen washout was always complete, all measurements were repeated. The patients breathed $100 \%$ oxygen for the rest of the study. Tolazoline $1 \mathrm{mg} / \mathrm{kg}$ was then given through the pulmonary artery catheter by bolus injection and all measurements were repeated five and 10 minutes after the drug had been given. Provided that mean aortic pressure had not fallen by more than $20 \mathrm{~mm} \mathrm{Hg}$, a further $1 \mathrm{mg} / \mathrm{kg}$ of tolazoline was then given and the measurements repeated. Finally, ranitidine $3 \mathrm{mg} / \mathrm{kg}$ was administered 10 minutes after the final dose of tolazoline by slow injection over five minutes through a peripheral venous cannula. The final measurements were made five and 10 minutes after the end of the injection of ranitidine.

\section{Results}

Measurements were made five and 10 minutes after each dose of each drug. There was no significant difference for any variable between the five and 10 minute measurements after any dose of either drug (Student's paired $t$ test). Analysis of the drug effects was therefore performed on the mean of the two measurements for each drug. The effects of tolazoline and ranitidine on the pulmonary and systemic circulations and heart rate are summarised in the Table and the Figure. For statistical analysis the results have been expressed as percentages of the values on $100 \%$ oxygen before administration of the drugs because of the wide variation in baseline measurements between individuals. Paired $t$ tests have been used throughout.

The first dose of tolazoline $1 \mathrm{mg} / \mathrm{kg}$ resulted in a fall in pulmonary vascular resistance (PVR) (mean $(\mathrm{SEM})$ fall $10 \cdot 0(3 \cdot 6) \%, \mathrm{p}<0 \cdot 05)$. A second bolus of tolazoline $1 \mathrm{mg} / \mathrm{kg}$ was given to 10 children, but 


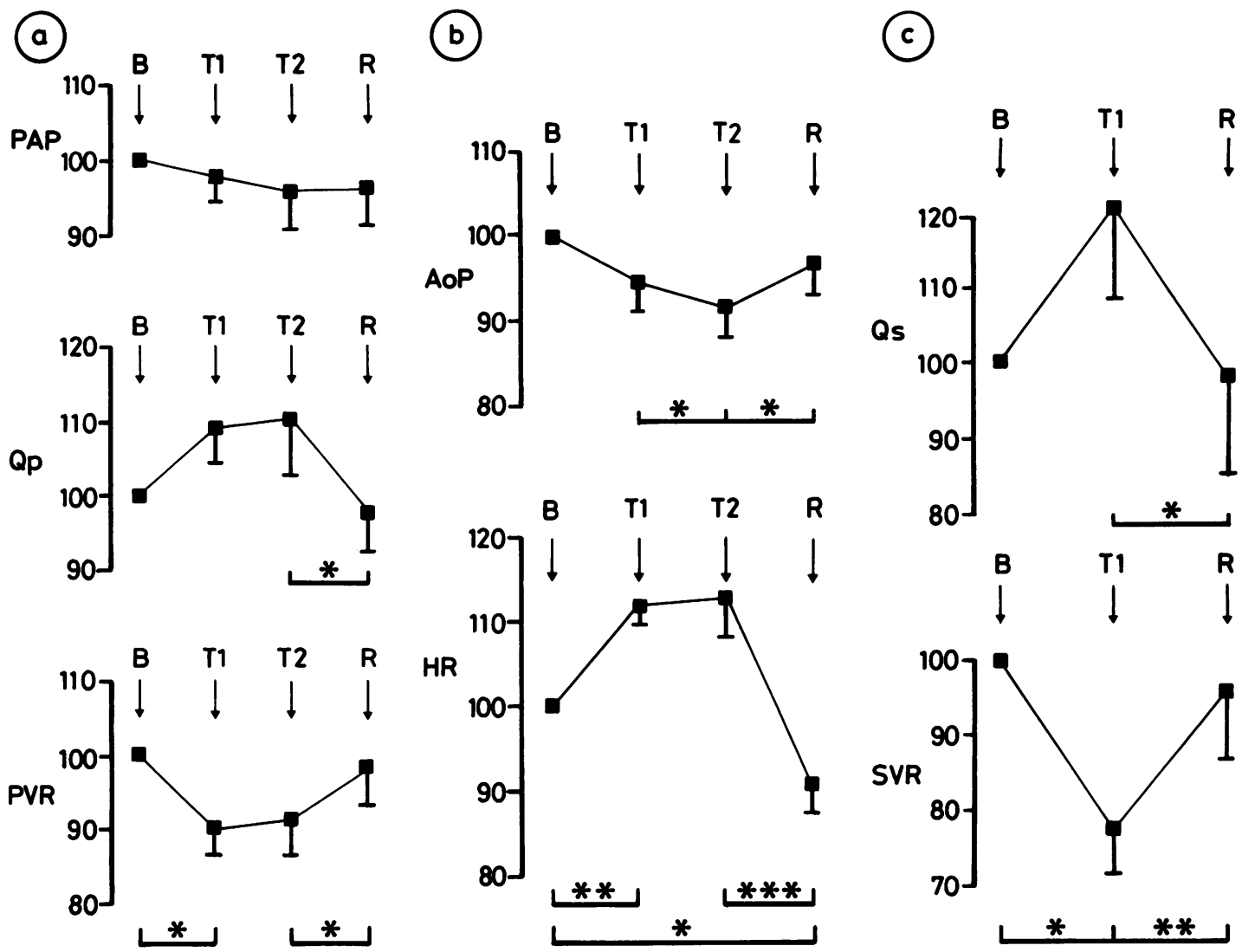

Figure Effects of tolazoline and ranitidine on the pulmonary and systemic circulations and heart rates. $B=b a s e l i n e ;$ $T 1=$ first dose of tolazoline; $T 2=$ second dose of tolazoline; $R=$ after ranitidine. All effects are expressed as per cent change over baseline ( $100 \%$ oxygen).

(a) Effects on pulmonary artery pressure $(P A P)$, pulmonary blood flow $(Q p)$, and pulmonary vascular resistance (PVR);

(b) Effects on aortic pressure (AoP) and heart rate (HR);

(c) Effects on systemic blood flow (Qs) and systemic vascular resistance (SVR). Note only data for the first dose of tolazoline is available, and this figure is based on data for five patients.

${ }^{*} \mathrm{p}<0.05 ;{ }^{* *} \mathrm{p}<0.01 ;{ }^{* * *} \mathrm{p}<0.001$.

there was no significant additional fall in PVR for the group as a whole. Two children (cases 7 and 8) showed a further fall in PVR, however, greater than $10 \%$. Infusion of ranitidine reversed the fall in PVR previously produced by the tolazoline injections (mean (SEM) rise $8.7(3.5) \%, p<0.05)$, so that the final PVR, after both tolazoline and ranitidine had been given, did not differ significantly from that on $100 \%$ oxygen alone. Changes in PVR were due mainly to changes in pulmonary blood flow; pulmonary artery pressure did not change significantly at any time, in agreement with previous studies. ${ }^{810}$

Similar effects were found on the systemic circulation. The first dose of tolazoline caused a fall in mean aortic pressure (mean (SEM) fall $5 \cdot 4(3 \cdot 1) \%$, $\mathrm{p}=\mathrm{NS}$ ) and the second dose resulted in more pronounced hypotension (a further fall of 6.3 $(2.4) \%, p<0.05)$. This effect was also reversed by ranitidine (mean (SEM) rise in aortic pressure $7.4(2.9) \%, p<0.05)$, and the aortic pressure after administration of ranitidine did not differ significantly from that on $100 \%$ oxygen (baseline). We were able to measure systemic blood flow and systemic vascular resistance in five children in whom there were no intracardiac shunts at the time of study. There were sufficient data to analyse only the effects of the first dose of tolazoline. Systemic blood flow rose in four of the five children, but the result 
was not significant. When ranitidine was given systemic blood flow fell (mean (SEM) fall 21.1 $(9.8) \%, p<0.01)$ and returned to baseline rates. Similarly, systemic vascular resistance fell when tolazoline was given (mean (SEM) fall 22.8 $(12.9) \%, p<0.01)$ and rose to baseline levels after administration of ranitidine (mean (SEM) rise 21.8 $(9.4) \%, p<0.01)$. The ratio of pulmonary to systemic vascular resistance rose significantly after tolazoline (mean (SEM) rise $15 \cdot 8,(5 \cdot 3) \%, p<0.05)$ and fell to baseline levels after ranitidine (mean (SEM) fall $18 \cdot 7(5 \cdot 1) \%, \mathrm{p}<0 \cdot 05)$.

The heart rate results were different. The first dose of tolazoline caused tachycardia (mean (SEM) rise in heart rate $12.4(2.5) \%, \mathrm{p}<0.001)$, but there was no significant additional increase in heart rate after the second tolazoline bolus. When ranitidine was given heart rate fell (mean (SEM) fall 19.0 $(5 \cdot 1) \%, p<0 \cdot 01)$. After the administration of ranitidine heart rate was significantly lower than on $100 \%$ oxygen alone (mean (SEM) difference $9 \cdot 2(3 \cdot 1) \%$, $\mathrm{p}<0.05$ ), which contrasted with the other haemodynamic measurements.

\section{Discussion}

The major finding of this study was that $\mathrm{H}_{2}$ receptor blockade in children may have important cardiovascular effects. Intravenous ranitidine completely reversed systemic and pulmonary vasodilation induced by tolazoline and, in addition to reversing the tachycardia associated with tolazoline, seemed to have a direct negative chronotropic effect on the heart. The accuracy of the measurements, the assumptions that have had to be made, and the wider importance of these results are discussed below.

Cardiac output was measured by the direct Fick principle. Oxygen consumption was measured by remote respiratory mass spectrometry. ${ }^{78}$ This method has been compared with the standard technique using a gas meter and Douglas bag collection and the systematic error found to be equal to or less than $0 \cdot 6 \%$, with the standard deviation of single estimates plus or minus $3 \% .^{7}$ Blood gas analysis was performed on an automatic $\mathrm{pH}$ and blood gas electrode system (Corning 165). Studies with blood tonometered with physiological concentrations of oxygen and carbon dioxide have shown that this system measures blood gas tensions to an accuracy of $0.27 \mathrm{kPa}$. The effects of delays up to 20 minutes before analysing the blood samples have been shown to be negligible. ${ }^{8}$

In the presence of intracardiac right to left shunts (seven patients) the use of an aortic rather than a pulmonary vein sample in the Fick equation would result in overestimation of pulmonary blood flow. We therefore used the alveolar air equation to predict the oxygen content of pulmonary end capillary blood, substituting this for pulmonary venous blood in the Fick equation, thus measuring effective pulmonary blood flow. In the presence of parenchymal lung disease this approximation would be inaccurate. None of these seven patients, however, had any clinical or radiological evidence of lung disease. The alternative of repeated manipulations of the right heart catheter from the pulmonary artery into the pulmonary veins through any interatrial communication for each measurement would have prolonged the procedure unacceptably. In three patients we compared predicted pulmonary end capillary blood oxygen content with pulmonary vein blood oxygen content on five occasions. Agreement was good (mean (SE) difference $0.49(0.17)$ $\mathrm{mg} / \mathrm{dl}$ ). In three further patients aortic blood saturation was greater than $99 \%$ on $100 \%$ oxygen, despite angiographic evidence of right to left intracardiac shunting. This suggests that there were no large areas of ventilation to perfusion mismatch in at least six of the children in whom the alveolar air equation was used (cases 3, 5, and 7-11). Further discussion of the use of the alveolar air equation under these circumstances can be found elsewhere. ${ }^{10}$

It is important to keep the duration of general anaesthesia as short as possible and this imposed some constraints on the timing of measurements. The circulatory effects of tolazoline have been reported to reach a plateau within five to 10 minutes of a bolus injection and to remain unchanged for four to six hours. ${ }^{211}$ There was no significant difference between the measurements five and 10 minutes after the bolus, and so we assumed that a plateau had been reached, and the mean of the two measurements was used for comparisons. Ideally, we would have checked this assumption by making further measurements before giving ranitidine. There is no information about the speed of onset of any cardiovascular effects of ranitidine in children, and we would have liked to have examined the time course of its effects. Further extending the duration of the catheterisation and the general anaesthetic, however, could not be justified and so we were unable to determine the maximum circulatory response to ranitidine or its duration of action. From our measurements it seemed that the effects may have reached a plateau, but there is no conclusive proof of this.

This study has confirmed that tolazoline is a pulmonary vasodilator that also has pronounced systemic effects, notably tachycardia and hypotension. In the past these effects have generally been attributed to blockade of cardiovascular alpha 
adrenergic receptors, ${ }^{13}$ although there have been suggestions that histamine receptors are important. ${ }^{6}$ Systemic hypotension limits the doses of tolazoline that can be given safely. Tolazoline has many other side effects, including gastrointestinal bleeding, presumably related to its $\mathrm{H}_{2}$ agonist properties. ${ }^{2}$ It seemed rational to give an $\mathrm{H}_{2}$ blocking agent to prevent this potentially life threatening side effect. Ranitidine was chosen because it is reported to have only $\mathrm{H}_{2}$ antagonist properties, whereas cimetidine also has gonadotrophic and other effects. ${ }^{12}$ When ranitidine was infused intravenously, however, the vasodilator effects seen after tolazoline were totally abolished five and 10 minutes after the end of the infusion, suggesting that the cardiovascular effects of tolazoline may be mediated by $\mathrm{H}_{2}$ receptors. Heart rate after ranitidine was significantly lower than baseline, suggesting that ranitidine has a direct negative chronotropic effect.

Ranitidine acted as a systemic and pulmonary vasoconstrictor. At the time of its administration the children were exposed to two pulmonary vasodilators, $100 \%$ oxygen and tolazoline. The effects of ranitidine on the pulmonary circulation could therefore be a result of blockade of either or both vasodilators or by an entirely independent mechanism. We cannot distinguish between these possibilities, but the most probable explanation is that ranitidine blocked the effects of tolazoline on the pulmonary vasculature. Experimental work on animals suggests that histamine is not involved in the modulation of the response of the pulmonary circulation to changes in alveolar oxygen tension. ${ }^{13}$ Other workers have suggested that the $\mathrm{H}_{2}$ agonist effects of tolazoline may be more important than the alpha adrenergic antagonist activity in the pulmonary circulation," and our results support this. A direct effect of ranitidine on pulmonary vascular resistance cannot be excluded as it was not given to patients who had not been pretreated with tolazoline. Ranitidine could also have interacted with receptors other than $\mathrm{H}_{2}$ receptors, but no such effects have ever been reported.

Studies on the circulatory effects of histamine and $\mathrm{H}_{1}$ and $\mathrm{H}_{2}$ receptor blockade have produced conflicting results, suggesting that there may be age and species related differences in effects. When newborn lambs have been made hypoxic to raise the PVR histamine infusions have caused pulmonary vasodilation and, at larger doses, systemic vasodilation. ${ }^{1.3}$ The pulmonary effects were mediated by both $\mathrm{H}_{1}$ and $\mathrm{H}_{2}$ receptors. Similar findings have been reported in fetal lambs, ${ }^{14}$ calves, ${ }^{15}$ and adult cats. ${ }^{16}$ In adult animals histamine may constrict or dilate pulmonary arteries. ${ }^{13-16}$

Although histamine causes a fall in pulmonary and systemic vascular resistances in normal adult humans ${ }^{17}$ it has been shown to cause contraction of isolated strips of human pulmonary artery and vein. ${ }^{18}$ There were no changes in pulmonary and systemic haemodynamics in 10 patients with chronic obstructive lung disease and five otherwise normal patients with duodenal ulcers given ranitidine ${ }^{19}$ nor in seven adults with portal hypertension given cimetidine ${ }^{20} \mathrm{~A}$ rise in pulmonary artery pressure was observed in a child given cimetidine for acute gastrointestinal haemorrhage induced by tolazoline, the pressure having previously fallen after tolazoline. ${ }^{2}$ No measurements of pulmonary or systemic vascular resistances were made, however, on that child.

We conclude from our data that there may be $\mathrm{H}_{2}$ receptors within the pulmonary and systemic circulations of children. The most probable explanation of our results is that stimulation of these receptors caused vasodilation and that blockade (at least of the stimulated receptor) caused vasoconstriction in both circulations. In addition, ranitidine seemed to have a direct negative chronotropic effect on the heart. These observations have clinical as well as theoretical importance. Clearly, $\mathrm{H}_{2}$ receptor antagonists should not be used as treatment or prophylaxis for gastrointestinal haemorrhage induced by tolazoline, confirming previous findings. ${ }^{2}$ The possibility of adverse cardiovascular effects in other children receiving oral $\mathrm{H}_{2}$ blockers, particularly those with pulmonary hypertension, should be borne in mind. The safety of these agents in infants and children requires further investigation.

$\mathrm{AB}$ is supported by the British Heart Foundation.

\section{References}

' Rudolph AM, Paul MH, Sommer LS, Nadas AS. Effects of tolazoline hydrochloride (Priscoline) on circulatory dynamics of patients with pulmonary hypertension. Am Heart J 1958;55: 425-32.

2 Jones ODH, Shore DF, Rigby ML, et al. The use of tolazoline hydrochloride as a pulmonary vasodilator in potentially fatal episodes of pulmonary vasoconstriction after cardiac surgery in children. Circulation 1981:64(Suppl II):134-9.

${ }^{3}$ Goctzman BW, Sunshine P, Johnson JD, et al. Neonatal hypoxia and pulmonary vasospasm: response to tolazoline. $J$ Pediatr 1979:89:617-21.

+ Socha J, Rondio H, Chaba-Celinska D, Rasinski A, Bogoniowska Z. Ranitidine treatment of peptic and related diseases in children. In: Misiewicz JJ, Wormsley KG, eds. The clinical uses of ranitidine. Medicine Publishing Foundation, 1982:305-9.

5 McAuley DM, Moore J, McCaughey W, Donnelly BD, Dundee JW. Ranitidine as an antacid before elective caesarian section. Anaesthesia 1983;38:108-14.

- Goctzman BW. Milstein JM. Pulmonary vasodilator action of tolazoline. Pediatr Res 1979:13:942-4.

7 Davies NJH, Denison DM. The measurement of metabolic gas 
exchange by mass spectrometry alone. Respir Physiol 1979;36:261-7.

${ }^{8}$ Davies NJH, Shinebourne EA, Scallan MJ, Sopwith TA, Denison DM. Pulmonary vascular resistance in children with congenital heart disease. Thorax 1984;39:895-900.

9 Kelman GR. Digital computer subroutine for the conversion of oxygen tension into oxygen saturation. J Appl Physiol 1966;21:1375-6

${ }^{10}$ Bush A, Busst CM, Booth K, Knight WB, Shinebourne EA. Does prostacyclin enhance the selective pulmonary vasodilator effect of $100 \%$ oxygen? Circulation 1986;74:135-44.

"Reynolds JGF, ed. Martindale: the extra pharmacopoeia. 28th ed. London: The Pharmaceutical Press, 1982:1633.

12 Van Thiel DM, Gavalier JS, Smith WI, Paul G. Hypothalamicpituitary-gonadal dysfunction in men using cimetidine. $N$ Engl $J$ Med 1979;300:1012-5.

13 Goetzman BW, Milstein JM. Pulmonary vascular histamine receptors in newborn and young lambs. $J$ Appl Physiol 1980;49:380-5.

14 Levin DS, Ruldolph AM, Heymann MA, Phibbs RH. Morphological development of the pulmonary vascular bed in fetal lambs. Circulation 1976;53:144-51.

15 Okpako DT. A vasodepressor action of histamine mediated by H2 receptor activation. Eur J Pharmacol 1974;29:10-4.
${ }^{16}$ Barer GR, Emery CJ, Mohammed FH, Mungall IPF. H1 and $\mathrm{H} 2$ histamine actions on lung vessels: their relevance to hypoxic vasoconstriction. $Q J$ Exp Physiol 1978:63:157-69.

${ }^{17}$ Bjure J, Helander E, Lindell S-E, Soderholm B, Westing H. Effect of acetyl choline and histamine on the pulmonary circulation in normal men and women. Scandinavian Journal of Respiratory Diseases 1967;48:214-26.

${ }^{18}$ Mikkelsen EO, Sakr AMR, Jesperson LT. Effects of nifedipine on contractile responses to potassium, histamine and 5-hydroxytryptamine in isolated human pulmonary vessels. $J$ Cardiovasc Pharmacol 1983;5:317-20.

${ }^{19}$ Chow JSF, Wong RYC, Wong PHC, Chen WWC, Lai CL. Intravenous ranitidine has no haemodynamic effects in subjects with normal lung function and patients with chronic obstructive airway disease. Aust NZ J Med 1983;13:261-3.

20) Herz R, Rossle M, Bonzel T, Keller E, Gerok W. Effect on cimetidine on the hepatic extraction of indocyanine green, the portal pressure and the systemic circulation in patients with cirrhosis of the liver. Klin Wochenschr 1984;62:759-64.

Correspondence to Dr E A Shinebourne, Department of Paediatric Cardiology, Brompton Hospital, Fulham Road, London SW3 6HP.

Received 28 August 1986 